\title{
Is Turkey Ready for Global Network in the Perspective of European Union?
}

\author{
Doç. Dr. Bahar BERBEROĞLU ${ }^{1}$ \\ Anadolu University, Open Education Faculty, \\ Deparment of Economic and Administrative Programs, Eskişehir, Turkey \\ Prof. Dr. C. Necat BERBEROĞLU² \\ Anadolu University, Faculty of Economics and Administrative Sciences, \\ Department of Economics, Eskişehir, Turkey
}

\begin{abstract}
While the European Union, was initially founded as an association for economic purposes, now it tends to be a common information society and wants to transform the economic structure of the Union in the perspective of knowledge economy. World Economic Forum derived the networked readiness index which consists four sub-indices as environment, preparation, usage and impact sub-indices, with the aim of using it in evaluating the levels of development of the countries in transforming themselves into information societies. In this study, we primarily evaluated the positions of Turkey and the countries of European Union within the scope of the networked readiness index, then we evaluated their positions according to the impact sub-index. Impact sub- index can be separated into two groups both including four different sub-indices as economic and social ones. In our study we preferred to use clustering analysis which is one of the multivariate statistical techniques and employed a non-hierarchical clustering analysis named k-means technique. According to the networked readiness index, Finland was in the best position and followed by Sweden, UK, Denmark, Germany, Luxembourg and Netherlands. Turkey took part in the bottom cluster, along with other European Union countries. On the other hand according to the impact sub-index, while Turkey was found to be in the moderate position among the European Union Countries, Sweden, UK, Malta, Netherlands, Luxembourg, Poland, Estonia and Finland were in the best position.
\end{abstract}

Keywords:EuropeanUnion, Knowledge Economy, Networked Readiness Index, ImpactSubindex, k-means Cluster analysis

\section{Introduction}

Although the interests of the economists in technology date back to quite a long time ago, it is fairly new that they turned them into a central subject within economic thinking. There is an important role of the sovereignty of the economic approach in which especially technology is accepted externally and the fact that the effects of technologic developments on the economic and social structure are quite limited. That the

\footnotetext{
${ }^{1}$ Bahar Berberoğlu, Associate Professor Doctor, Anadolu University, Open Education Faculty, Deparment of Economic and Administrative Programs, YunusEmre Campus, Eskişehir, Turkey e-mail: bdirem@anadolu.edu.tr

${ }^{2}$ CaferNecatBerberoğlu, Professor Doctor, Anadolu University, Faculty of Economics and Administrative Sciences, Department of Economics, YunusEmre Campus, Eskişehir, Turkey
} 
effects of technologic advancements in general, and specifically the advancements in Information and Communication Technologies (ICT) on macro and micro economic variables and primarily economic growth are revealed led economists to become more closely interested in this subject (Yumuşak, Erarslan \& Bayraktar, 2010).

Information and communication-based business lines replace the business lines in traditional industrial areas with the development of ICT sector in the world. The national income of the countries investing in ICT is increasing more rapidly. Services such as mobile and cell phone, the internet, cable TV and electronic trade further develop under the name of new economy (Savrul \& Kılıç, 2011). When ICT is used actively, it creates the opportunity to perform mobile trade by reducing the place and place-related expenses through e-trade and e-entrepreneurship, and this increases the participation of especially young people and women in the labour force and their employment (Bozkurt, 2014-2015). ICT makes turning tacit knowledge into open knowledge technically possible and economically attractive (Yavaş, 2014).

Information Society is a phenomenon that extends and develops the relationship between education and productivity. The information society plays a critical role in ensuring increased productivity by providing effective use in processes of producing, processing, storing and sharing the information, easy access and decision making, creation of new organizational structures and business process, and the access to new markets. It is seen that economies that create science and technology, use information and technology as an effective tool and create more values with information-based decision-making processes gain visibly more success in global competition (TUSIAD, 2015).

The elements that play an important role in ensuring rapid and sustainable economic growth and development of a country are universities, science and technology centres, research institutions, human capital, and industrial institutions that can perform advanced technological production and have a high added value. If a country can invest sufficiently in Research and Development (R\&D), make new inventions and start mass production with high technology products that will create added value by obtaining patents from patent offices with international reputability, and if it can export those products, the country can easily achieve sustainable economic wealth and prosperity (Özbek \& Atik, 2013).

The Networked Readiness Index (NRI) is an index that performs the analysis of how much the countries are ready for using ICT while also revealing the extent to which they internalize these technologies in an individual, public administration and throughout the business world. This index consists of the sub-indices of Environment, Readiness, Usage and Impact. The impact sub-index consists of the economic and social indicators of countries. Here, we assessed the situation of Turkey with the European Union countries both by the Networked Readiness Index and the Impact sub-index. There are both ranking and index values for this index. However, only the index values were used in this study.

\section{Networked Readiness IndexandImpactSubindex}

The NRI which is prepared in order to comparatively measure the levels of countries in the field of ICT, consists of 4 components and 54 related indicators. 4 components of this index being the environment, readiness,usage and the impact sub-indices are shown in Figure 1. 


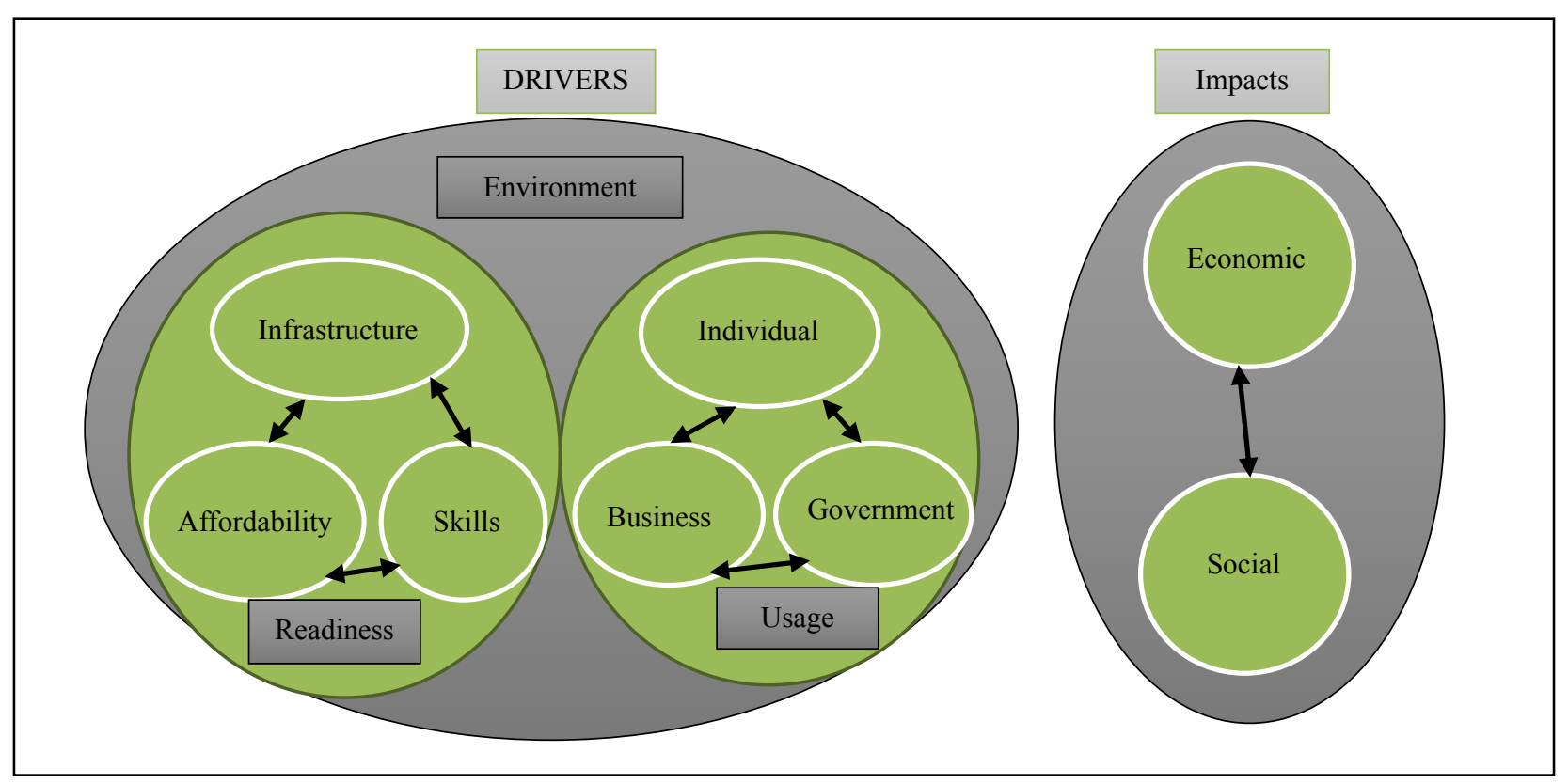

Figure 1. The Evolved Framework, Source:WEF (2014).

The environment component consists of the political and regulatory environment indicator together with business and innovation environment indicators. Readinesscomponent is expressed with the infrastructure, affordability and skills indicators. While usage is expressed with individual, business world and government indicators (Yumuşak \& Bilen, 2011).

The NRI measures the capacities of the economies to benefit from ICT in the best way in order to increase their innovation, competitiveness and development levels (Kalayc1, C. 2013). In other words, it shows the digitalization level of the countries, since digitalizationand transnational digital divisiondepend on the socio-economic factors of developed and developing countries. The substructure investments in ICT are quite insufficient especially in countries with insufficient economic, social and cultural development levels and low income. Thus, the production and provision of the technologies related to ICT are quite insufficient in such countries. The inequalities between countries with different development levels further deepen depending on the rapid development of ICT (Bal, Kalayc1 \& Artan 2015). Some researchers say that it is possible that developing countries may catch up with developed countries after some time with the developing effect of ICT depending on the increase in the internet use of the digital gap between countries (Negroponte, 1998).

This index calculation method was developed in such a structure that it will better respond to today's necessities with the ongoing improvements so far. When calculating the index, the data are first turned into a scoring between 1 and 7. Then, each sub-index is calculated by taking the weighted average of the data constituting it. Finally, the NRI value is determined by taking the average of constituting 4 sub-indices (Karaata, 2012). When the index value is close to 7 , itshows that the country has quite a developed structure with regard to ICT, and respectively if the valueof the index is close to 1 , it indicates that the countryisquite underdeveloped (Kalayc1, C. 2013).

The Impact sub-index which is the subject of this study consists of economic and social effects. While 3 Nordic countries, Finland, Sweden, and Norway, are among the top 5 countries in the rankings in the Networked Readiness Index, the remaining two Nordic countries, Denmark, and Iceland, ranked among top 20 
by showing a strong performance despite minor shifts seen in 2014. In terms of the readiness to ICT, the general performances, perfect digital infrastructures and strong innovation systems of these countries carry them to top ranking in the internet use and innovation performances around the world together with ICT. The Netherlands, Switzerland, the UK and the USA, which are the most developed economies of the West, that have understood the ICT potential in order to create a new economic and social revolution made significant investments in order to develop their digital potentials.

The social effect grounds that consist of the other four variables aim to measure ICT-based improvements resulting from such phenomena as the environment, education, energy consumption, health, or more active civic participation. Here, due to data limitations, this ground focuses on measuring the efforts of governments to increase the e-participation of the citizens, therefore, ensure their being more effective in the ICT use and provide them better online services. Furthermore, these social effect grounds measure the ICT use level in education considering the potential benefits of the ICT use in this area.

In general, it is not easy to measure the effects of ICT. The development of rigorous quantitative data required to do this is still in its infancy. Consequently, as the direct results of the important impacts created by ICT on commercial activities are not realized, and the impacts on the environment and health are not yet fully understood, it is necessary to regard the Networked Readiness Index as an ongoing study. Furthermore, it should be expected that this index will be developed in such a way that it will include new data that are quite above today's dimensions.

Together with the information reform, ICT has turned the economic and social relationships into an intense form and ensured a very high-paced change by increasing the relationships between the stakeholders everywhere. In this environment, a new form that is different from the economic revolution periods created previously by gold and oil was revealed, and economic data were rendered producible in a raw and structured way. These data that bear high economic and social values became usable due to ICT (Bilbao-Osorio et al., 2014).

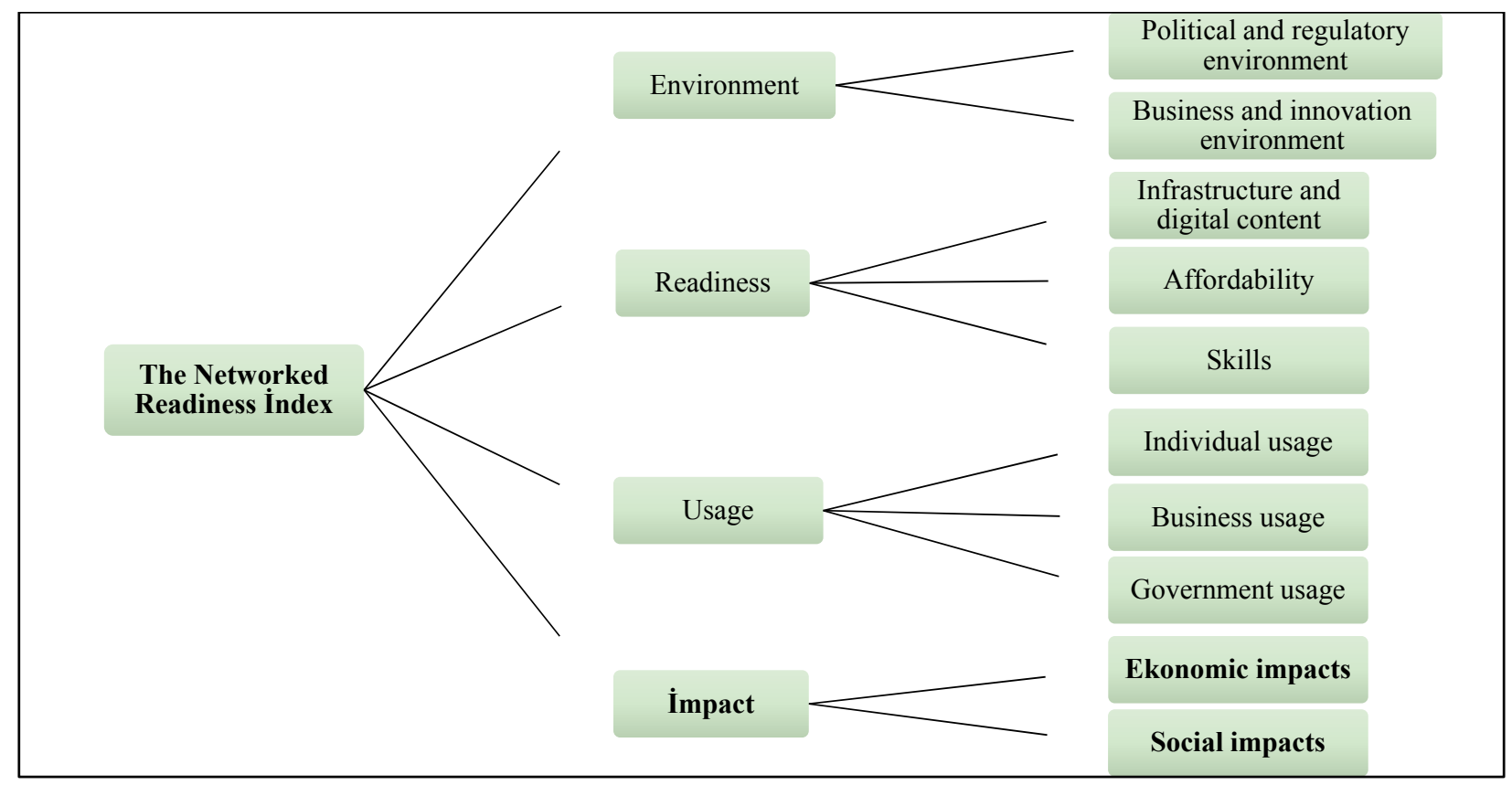

Figure 2. TheEvolvedNetworked Readiness Index Structure, Source:WEF (2014) 
Vicente and Lopez (2011) indicated that the countries in which English is the Native Language, are more advantageous in reaching ICT. Furthermore, they detected a positive and strong relationship among per capita income and skilled labour together with ICT, and a negative relationship between the local unemployment rate and the share of the $65+$ population within the total population with respect to ICT.

Cruz-Jesus, Oliveira and Bacao (2012) found that the integration process and economic richness are the main variables that explain digital divide for $27 \mathrm{EU}$ member countries. However, it was found out that the level of education is not a variable that explains digital divide, contrary to the expectations.

Pick and Nishida (2015) examined the factors affecting the technology use both at country level and local level in their studies covering 110 countries. Accordingly, they detected that the most important factors affecting the technology use in the world are higher education and innovation capacity. Upon examining at the regional level, theyfound that, judicial independence and innovation capacity were the most emphasized aspects in Europe. While higher education, foreign direct capital investments and innovation capacity came to the fore in Asia, and higher education, freedom of the press and foreign direct capital investments took the first place in Africa and Latin America (Bal, Kalaycı\&Artan, 2015).

\section{Countries in Our Analysis}

There are 29 countries in our analysis. These are Turkey and the EU member states. Hence, countries that were included in the analysis were put in order as follows: Belgium (B), Bulgaria (BG), Czech Republic (CZ), Denmark (DK), Germany (D), Estonia (EST), Ireland (IRL), Greece (GR), Spain (E), France (F), Italy (I), Cyprus (CY), Latvia (LV), Lithuania (LT), Luxembourg (L), Hungary (H), Malta (MT), Netherlands (NL), Austria (A), Poland (PL), Portugal (P), Romania (RO), Slovenia (SLO), Slovakia (SK), Finland (FIN), Sweden (S), United Kingdom (GB) and Turkey (TR).

\section{Metodology ve Application}

Clustering analyses were performed using the non-hierarchical k-means technique in this study. The $\mathrm{k}$-means technique used was designed in order to gather many units from the variable under $\mathrm{k}$ clusters. The number of clusters can generally be given as a particular value, and certain formulae were produced for this. Here, the number of clusters was found as $\mathrm{k}=(\mathrm{n} / 2)^{1 / 2}=(29 / 2)^{1 / 2}=3.08$, and approximately $\mathrm{k}=3$ (Berberoğlu, 2011).

\section{k-Means Technique}

Mac Quenn used the term of the k-means technique in order to define the algorithm that can divide each element with close values into clusters. This technique follows the following steps:

It divides the units into $\mathrm{k}$ clusters.

It is continued by gathering the units under the closest cluster in terms of the value. The distance is generally determined by using the "Euclidean distance." Then, the new value of the cluster is found by calculating the units. Thereafter, the new value of the cluster is found by calculating the mean value for the units.

Step 2 is repeated until there are no more allocations left (Norusis, 1993; Atamer, 1992).

The variables that we used for the Networked Readiness Index (NRI) are as follows:

AV: Environment subindex

BV: Readiness subindex 
CV: Usagesubindex

DV: Impactsubindex

Whether the NRI variables in our analysis are statistically significant can be understood from ANOVA table in Table 1.

Table 1

ANOVA table for $k=3$

\begin{tabular}{|c|c|c|c|c|c|c|}
\hline & \multicolumn{2}{|c|}{ Cluster } & \multicolumn{2}{|c|}{ Error } & \multirow{2}{*}{$-F$} & \multirow{2}{*}{$P$ value } \\
\hline & Mean Square & $\mathrm{df}$ & Mean Square & $\mathrm{df}$ & & \\
\hline $\mathrm{AV}$ & 3,809 & 2 & 070 & 26 & 54,090 & ,000 \\
\hline BV & 1,564 & 2 & ,089 & 26 & 17,496 &, 000 \\
\hline $\mathrm{CV}$ & 6,673 & 2 &, 058 & 26 & 114,629 &, 000 \\
\hline DV & 8,330 & 2 & ,101 & 26 & 82,700 &, 000 \\
\hline
\end{tabular}

It is seen when above-stated Table 1 ANOVA table is checked that the variables AV, BV, CV, and DV were significant by $5 \%$. The following Table 2 was created in order to show which countries are included in which cluster by cluster number $\mathrm{k}=3$ :

Table 2

Countries and Clusters for Netwoked Readiness Index

\begin{tabular}{lll}
\hline $\begin{array}{l}\text { Cluster } \\
(\mathrm{k}=3)\end{array}$ & Number of Cases in Each Cluster & Countries \\
\hline 1 & 13 & TR, RO, BG, LV, H, GR, PL, SK, SLO, CR, CY, CZ, I \\
2 & 7 & FIN, S, D, UK, NL, DK, L \\
3 & 9 & B, A, F, E, IRL, EST, LT, ML, P \\
\hline
\end{tabular}

Turkey is in Cluster 1, and the other elements of this cluster are Romania, Bulgaria, Latvia, Hungary, Greece, Poland, Slovenia, Slovakia, Cyprus, Czech Republic, Croatia, and Italy.

Box defined the $\mathrm{M}$ statistics for the assumption of the equality of covariance matrices in the discriminant analysis. Box's M statistics was obtained by generalizing the Barlett-Box F test, which is a single variable ( $p=1$ ) covariance test. It is necessary that group covariance matrices are homogeneous in order to be able to apply the discriminant analysis in this study. We tested this using Box's M test. Moreover, the statistics used in testing the equality of covariance matrices are sensitive to normality assumption. The deviation from normality is also shown using Box's M test (Kalayc1, Ş. 2008). Box's M statistics is found higher than $0.05(0.087>0.05)$, and this indicates that the discriminant analysis can be applied.

Table 3

ClassificationResults

\begin{tabular}{|c|c|c|c|c|c|c|}
\hline & & \multirow{2}{*}{ Cluster number of case } & \multicolumn{3}{|c|}{ Predicted Group Membership } & \multirow{2}{*}{ - Total } \\
\hline & & & 1 & 2 & 3 & \\
\hline \multirow{6}{*}{ Original } & \multirow{3}{*}{ Count } & 1 & 13 & 0 & 0 & 13 \\
\hline & & 2 & 0 & 7 & 0 & 7 \\
\hline & & 3 & 0 & 0 & 9 & 9 \\
\hline & \multirow{3}{*}{$\%$} & 1 & 100,0 &, 0 &, 0 & 100,0 \\
\hline & & 2 &, 0 & 100,0 &, 0 & 100,0 \\
\hline & & 3 & 0 &, 0 & 100,0 & 100,0 \\
\hline
\end{tabular}


According to Table 3, the clusters are classified 100\% correctly. That the distances from the centre of the clusters are normally distributed is another condition that must be taken into consideration in the clustering analysis. Accordingly, the Kolmogorov-Smirnov test was performed, and it was understood that the normality assumption was fulfilled.

The indicators of the impact sub-index are as follows:

\section{Economic Impacts}

v901: Impact of ICTs on new services and products. In your country, to what extend do ICTs enable new business model? ( $1=$ not at all; $7=$ to a great extent) 2012-2013 weighted average.

v902: PCT ICT patent applications. Number of applications for information and communication technology-related patents filed under the Patent Cooperation Treaty (PCT) per million population

v903: Impact of ICTs on new organizational models. In your country, to what extent do ICTs enable new organizational models (e.g., virtual teams, remote working, and telecommuting) within businesses? (1= not at all; $7=$ to a great extent) 2012-2013 weighted average.

v904: Share of workforce employed in knowledge-intensive activities (\%) 2012.

Social Impacts:

v1001: Impact of ICTs on Access to basic services. In your country, to what extent do ICTs enable Access for all citizens to basic services (e.g. health, education, financial services, etc.)? $(1=$ not at all; $7=$ to a great extent) 2012-2013 weighted average.

v1002: Internet access in schools. In your country, how widespread is internet access in schools? $(1=$ not at all; $7=$ to a great extent) $2012-2013$ weighted average.

v1003: ICT use and government efficiency. In your country, to what extent does the use of ICTs by the government improve the quality of government services to citizens? ( $1=$ not at all; $7=$ to a great extent) 2012-2013 weighted average.

v1004: E-Participation Index. E-Participation Index assesses, on a 0-to-1 (best) scale, the quality, relevance, and usefulness of government websites in providing online information and participatory tools and services to their citizens. 2012 (WEF, 2014)

In this study, there is the data set that includes 29 countries and 8 variables which belong to the Impact sub-index. However, some of these have the 2012-2013 weighted average value and may get values in the interval between $[1,7]$. The analysis was performed using 5 variables for this purpose. ANOVA table is shown as follows in the analysis performed with the cluster number $\mathrm{k}=3$ :

Table 4

ANOVA table

\begin{tabular}{lllllll}
\hline & \multicolumn{2}{c}{ Cluster } & \multicolumn{2}{c}{ Error } & P value \\
\cline { 2 - 7 } & MeanSquare & s.d. & MeanSquare & s.d. & 55,166 &, 000 \\
\hline v1003 & 6,304 & 2 &, 114 & 26 & 21,585 &, 000 \\
v1002 & 5,311 & 2 &, 246 & 26 & 62,364 &, 000 \\
v1001 & 6,639 & 2 &, 106 & 26 & 35,678 &, 000 \\
v903 & 4,393 & 2 &, 123 & 26 & 38,241 &, 000 \\
v901 & 4,376 & 2 &, 114 & 26 & \\
\hline
\end{tabular}

As is seen from Table 4 , the variables are statistically significant at the significance level of $5 \%$. Table 5 was created in order to be able to show the clusters to which the countries belong: 
Table 5

CountriesandClustersforImpactSubindex

\begin{tabular}{lll}
\hline $\begin{array}{l}\text { Cluster } \\
(\mathrm{k}=3)\end{array}$ & Number of Cases in Each Cluster & Countries \\
\hline 1 & 14 & TR, LV, LIT, B, A, H, D, E, F, SLO, CY, CZ, DK, IRL \\
2 & 7 & RO, BG, GR, PL, SK, CR, I \\
3 & 8 & S, UK, ML, NL, P, EST, FIN, L \\
\hline
\end{tabular}

Turkey is in Cluster 1, and the other elements of this cluster are Lithuania, Latvia, Belgium, Austria, Hungary, Germany, Spain, France, Slovenia, Cyprus, Czech Republic, Denmark, and Ireland.

In this study, the homogeneity of group covariance matrices was tested using Box's M test. The Box's M statistics was found higher than $0.05(0.227>0.05)$. Thus, we could apply the discriminant analysis.

Table 6

ClassificationResults

\begin{tabular}{|c|c|c|c|c|c|c|}
\hline & & \multirow{2}{*}{ Cluster number of case } & \multicolumn{3}{|c|}{ Predicted Group Membership } & \multirow{2}{*}{-Total } \\
\hline & & & 1 & 2 & 3 & \\
\hline \multirow{6}{*}{ Original } & & 1 & 13 & 0 & 1 & 14 \\
\hline & Count & 2 & 0 & 7 & 0 & 7 \\
\hline & & 3 & 0 & 0 & 8 & 8 \\
\hline & & 1 & 92.9 & .0 & 7.1 & 100.0 \\
\hline & $\%$ & 2 & .0 & 100.0 & .0 & 100.0 \\
\hline & & 3 & .0 & .0 & 100.0 & 100.0 \\
\hline
\end{tabular}

The clusters are classified correctly at $96.6 \%$ according to Table 6 . This is quite a high clustering success.Germany was included in Cluster 3 according to the discriminant analysis,while this country was located in Cluster 1 in the clustering analysis. The condition that the distances from the centre of the cluster are normally distributed was taken into consideration here, too. The Kolmogorov-Smirnov test was performed, and it was understood that the normality assumption was fulfilled.

\section{Conclusion}

The NRI was calculated for 142 countries according to the report of 2012, and for 148 countries according to the report of 2014. The subject is addressed only in the framework of the European Union and Turkey. The European Union member countries that are in the best situation in our analysis according to the NRI are Sweden, England, Germany, Denmark, Luxembourg, Netherlands and Finland. This is the second cluster, and the third cluster follows the complaining second cluster. The elements of the third cluster are Belgium, Austria, France, Spain, Estonia, Lithuania, Malta, Portugal and Ireland. The lowest cluster and the cluster with the lowest value in terms of the networked readiness index is the first cluster. The first cluster consists of Turkey, in addition to 13 other European Union member countries. These are Greece, Bulgaria, Hungary, Czech Republic, Cyprus, Croatia, Italy, Latvia, Poland, Romania, Slovakia, and Slovenia. This is understood from the cluster distances shown in Table 7.

While Nordic economies such as Sweden, Denmark, and Finland are at the top place, these are followed by Germany, UK, Netherlands, and Luxembourg. The 3rd cluster follows the 2 nd a bit closer. This distance value is regarded as 1.454 . The $3 \mathrm{rd}$ cluster is followed by the 1 st with the distance value of 1.492 . The distance between the 2 nd cluster and the 1 st is 2.943 . 
Table 7

Networked Readiness Index Distances by k-meansteknique

\begin{tabular}{llll}
\hline \multicolumn{4}{c}{ Distancesbetween Final Cluster Centers } \\
\hline Cluster & 1 & 2 & 3 \\
\hline 1 & 2,943 & 2,943 & 1,492 \\
2 & 1,492 & & 1,454 \\
3 & 1,454 & \\
\hline
\end{tabular}

In our analysis according to the impact sub-index, the European Union member countries in the best position are Sweden, the UK, Malta, Netherlands, Portugal, Estonia, Luxembourg, and Finland. This is understood from the cluster distances shown in Table 8.

Table 8

ImpactSubindexDistancesby k-meansteknique

\begin{tabular}{lllc}
\hline \multicolumn{4}{c}{ Distancesbetween Final Cluster Centers } \\
\hline Cluster & 1 & 2 & 3 \\
\hline 1 & & 2.062 & 1.746 \\
2 & 2.062 & & 3.801 \\
3 & 1.746 & 3.801 & \\
\hline
\end{tabular}

While Nordic economies such as Sweden and Finland rank at the top place, these are followed by Denmark in a lower cluster. The distance value of the 3rd cluster made up by Sweden and Finland to the 1st cluster that follows it is regarded as 1.746 . The 1 st cluster is closer to the 3 rd cluster rather than the 2 nd cluster. This is understood from the distance values in Table 8 .

When Turkey is assessed according to the Networked Readiness Index, it ranks in the lowest cluster, while it ranks in the middle cluster according to the impact sub-index. Let us see this in Table 9:

Table 9

EU (average) andTurkeyComparison

\begin{tabular}{lllllllllllll}
\hline \multicolumn{1}{c}{ Netwoked Readiness Index } & \multicolumn{1}{c}{ ImpactSubindex } \\
\hline country & AV & BV & CV & DV & V1003 & V1002 & V1001 & V903 & V901 & V1004 & V904 & V902 \\
TR & 4.38 & 5.35 & 3.90 & 3.55 & 4.7 & 4.4 & 4.9 & 4.3 & 4.6 & 0.05 & 20.2 & 0.6 \\
EU & 4.63 & 5.62 & 4.76 & 4.36 & 4.47 & 5.39 & 4.8 & 4.54 & 4.79 & 0.38 & 38.41 & 19.41 \\
\hline
\end{tabular}

The variables that are included in the analysis in the table are shown in BOLD.

In Table 9, Turkey received a value above the European Union average only in V1003 and V1001 values. Accordingly, Turkey must be able to produce innovation by allocating more resources for R\&D expenses, and it must be able to produce these innovations especially in ICT sector.

In the 1980s, ICT was a production factor like capital and labour. Especially with the spread of globalization, ICT became a factor that supported the technologic development and increased productivity in the 1990s. As for today, it can be said that it is a factor that increases effectiveness/productivity in economic development, global integration, and the public sector, in addition to the contributions in 1980 and 1990 . It is seen that the countries failed to benefit equally from the rapid change and developments in ICT over the years. Developed countries withhigh-income levels and qualified human capital benefited from the positive economic and social effects of ICT to a great extent. The access to ICT and the gap in the ICT use in developed and 
developing countries gradually increase in parallel to the developments in ICT. Today, individual efforts in the European Union on this subject remain insufficient, and global cooperation becomes obligatory.

\section{References}

Atamer, B. (1992) Kümeleme Analizi ve Kümeleme Analizinin İlaç Sektöründe Uygulanması, Yayınlanmış Yüksek Lisans Tezi, İstanbul

Bal, H.Ç., Kalaycı, C. and Artan, S. (2015) Farklı Gelir Gruplarına Sahip Ülkelerde Dijital Bölünmenin Boyutu ve Belirleyicileri, Uluslararası Ekonomi ve Yenilik Dergisi, 1 (2): 107-123

Berberoğlu, B.(2011)Bilgi Toplumu ve Bilgi Ekonomisi Oluşturma Yolunda Türkiye ve Avrupa Birliği, Marmara Üniversitesi, Iktisadi ve Ídari Bilimler Fakültesi, XXIX, (2): 111-131

Bilbao-Osorio, B.,Crotti, R., Dutta, S. and Lanvin, B. (2014)The Networked Readiness Index 2014: Benchmarking ICT Uptake in a World of Big Data,

Bozkurt, Y. Ö. (2014-2015) İnovasyon, Teknoloji ve Ar-Ge Odağında 'Yeni İşler' ve İstihdam, İstihdamda 3i், İsgü̈cü, İşveren İşkur, Sayı 15, Kasım-Aralık-Ocak 2014-2015, Türkiye İş Kurumu Genel Müdürlüğü, ISSN: 1308-528x, pp. 44-49.

Cruz-Jesus, F.,Oliveira, T. And Bacao, F. (2012) Digital Divide Across the European Union, Information \& Management, 49: 278-291

Kalaycı, C. (2013)Dijital Bölünme, Dijital Yoksulluk ve Uluslararası Ticaret, Atatürk Üniversitesi İktisadi ve İdari Bilimler Dergisi, 27 (3): 145-162

Kalaycı, Ş. (2008)SPSS Uygulamalı Çok Değişkenli İstatistik Teknikleri, Asil Yayın Dağıtım LTD.ŞTİ. 3. Baskı, ISBN 975-9091-14-3, p.358

Karaata, E. S. (2012) Dünya Ekoomik Forumu Tarafından Yayınlanan(Bilişim Sektörü Perpektifinden) Birbiriyle Bağlantılı Olmaya (Şebekeler/ Ağlar İçinde Olmaya) Hazırlık Endeksi Hakkında Bilgi Notu Bankası, Briefs, No. 2012-3, TüsiadSabanc1 Üniversitesi Rekabet Forumu, pp. 1-13

Negroponte, N. (1998) The Third Shall Be First, Magazine, 01.01.98, (Access Date: 03.03.2015) http://www.wired.com/1998/01/negroponte-21/

Norusis, M. J. (1993) SPSS for Windows Release6.0 Advanced Statistics, SPSS Inc. Chigago, USA

Özbek, H. and Atik, H. (2013) İnovasyon Göstergeleri Bakımından Türkiye'nin Avrupa Birliği Ülkeleri Arasındaki Yeri: İstatistiksel Bir Analiz, Erciyes Üniversitesi İktisadi ve İdari Bilimler Fakültesi Dergisi, 42: 193-210.

Pick, J.B. and Nishida, T. (2015) Digital Divides in the World and its Regions: A Spatial and Multivariate Analysis of Technologigal Utilization, Technological Forecasting \& Social Change, 91:1-17

Savrul, B. K. and K1lı̧, C. (2011)Küreselleşme Sektöründe Bilişim Sektörünün Türkiye ve Avrupa Birliği Ülkelerinin Ekonomileri Üzerindeki Etkileri,İstanbul Üniversitesi, İktisat Fakültesi Mecmuası, 75. Yll Özel Saylsl, 61 (2): 258

TUSIAD (2015) (Access Date: 15.05.2015). http://www.tusiad.org.tr/temel-konular/uretkenlik-temelli-buyume--surdurulebilir-buyume/egitim--beseri-sermayenin-kalitesi -ve-bilgi-toplumu/

Vicente, M. R. andLo'pez, A. J. (2011)Assessing the Regional Digital Divide across the European Union-27, Telecommunications Policy, 35: 220-237

WEF. (2014)World Economic Forum, TheGlobal Information Technology Report 2014, Rewards and Risks of Big Data, (Access Date: 15.05.2015). http://reports.weforum.org/global-information-technology-report-2014/\#

Yavaş, H. K. (2014) Bilgi Ekonomisi ve Türkiye, TiSK Akademi, 2014/II, ISSN: 1306-6757, 9 (18): 48-73

Yumuşak, İ. G. and Bilen, M. (2011) Bilgi Ekonomisi, The Knowledge Economy, Seçilmiş bildiriler Kitabı, İstanbul Üniversitesi, İktisat Fakültesi, Editörler, Prof. Dr. Sedat Murat, Doç. Dr. İbrahim Güran Yumuşak, ISBN: 978-9944-0203-8-1, pp. $117-128$

Yumuşak, İ. G., Erarslan, C. and Bayraktar, Y. (2010)Küreselleşme Sürecinde Yeni Ekonomi ve İktisat Politikaları, Nobel Yayınları, 2 